\title{
Impact of Organizational Citizenship Behavior on Organizational Commitment on Jordanian Frontline Employees of Arabic Bank
}

\author{
Prof. Rashad Al Saed (PhD) \\ Dr. Al Hareth Hussein(PhD) \\ Amman Arab University; Business College, Business Department, Jordan
}

Doi:10.19044/esj.2019.v15n10p184 URL:http://dx.doi.org/10.19044/esj.2019.v15n10p184

\begin{abstract}
s
This study aims to investigate the impact of Organizational Citizenship Behavior on Organizational Commitment on employees of Arabic Bank The study population included of all Managers, assistant Managers and head of department in Arabic Bank branches at Amman Capital totaling (52) branches. The study sampling unit consists of individuals working at three managerial level (Managers, assistant Managers and head of department) in these branches totaling (128) individuals. To achieve the study objectives, the study used quantitative (descriptive analytical approach) through many statistical tools, most notably multiple regression analysis.

The study reveals a number of results namely: The organizational citizenship behavior (altruism, courtesy, Conscientiousness, sportsmanship, and civic virtue) have Impact on organizational commitment (Affective Commitment, Continuous Commitment \&Normative Commitment) on employees of Arabic Bank.

The study is proposed a few recommendations for Arabic branches; The management of Arabic bank should be considering to critical factors that influences citizenship behavior and employee commitment to improve the efficiency of the organization, not concentrating only on improving say infrastructure, rewards, improving technologies and their likes.
\end{abstract}

Keywords; Organizational Citizenship, Organizational Commitment, and Arab Bank branches

\section{Introduction:}

In today's world, the quantity and quality of goods and services have undergone profound changes due to economic growth and development. The monopoly competition has gradually vanished, and customers feel more free to select the most apposite products in goods and services which cause the 
rivalry to appears. All financial and non-financial institutions and organizations are competing to sell their products or service for customers. Because their existence depends on the number of their customers. The act of behavior of organizational citizenship is expressed like respectable soldiers, random behavior, deliberate behavior and useful performance, produces a new expression in the discipline of the organization, especially in the organization behavior, which is important in the emotions of the organization. Garg and Rastogi, 2006). OCB is closely related to organizational commitment. In the last two decades, researchers have considered organizational commitment to be a prevailing subject of super-analysis; contemporary attitudes toward organizational commitment are a multidimensional attitude, so the work of other researchers can be seen as Specify various commitments to the behavior of the work environment (Dickinson 2009).

Organizational commitment is a psychological state of classification, the relationship between employees and organizations is expected as a commitment to the whole organization. The three dimensions of the commitment have been known, respectively is linked to Employees of your organization, but the environment of "psychological alliances" is dissimilar. Affective Commitment (AC) connects employees through their participation and connection. Continuity commitment (CC) depends on the employee, be aware of the cost of leaving the organization. Normative Commitment (NC) is based on a strong feeling of employees for colleagues or managers. Every component can have different backgrounds, although they all end to a reduction in intentions to exit from the organization, leading to employee extra and discretionary role behaviors to produce different results (Gautam, Van Dick \& Wagner, 2001

In recent years, many researchers have been a favorite in organizational behavior and favorite psychology (Rokni nezhad, 2007). Over the past three decades' attitude has some changes, and conceivably the most significant of this change is in the relevant areas of the concept's multidimensional to onedimensional approach. New changes in the commercial area, including staff reductions and mergers of companies, have led some experts to announce the impact of organizational commitments on other important variables in the management area, such as "dereliction of duty, absenteeism and performance". However other researchers have rejected these results which organizational commitment has not lost its importance and can still be considered (Farhangi, 2005).

From the above introduction, the idea of this research comes to investigate the impact of organizational citizenship behavior on organizational commitment. The conceptual basis and research hypotheses for research are created in the next section (see the model in Figure 1). 


\section{Theoretical Framework of the Study}

\section{Organizational citizenship Behavior}

Organizational behavior of Citizenship (OCB) is discretionary, not directly or explicitly accepted by the formal compensation system and represents individual actions that promote the effective functioning of the organization (Organ, 1988). Turnipseed and Rassuli (2005) defined the OCB as an organization's defense when the OCB was criticized, or when peers were encouraged to invest in the organization, this means that the OCB is "beyond duty". The definition of OCB was used and developed by organ who wrote a formal definition in 1988 that OCB "is discretionary and is an individual action promoting the effective function of the organization, not explicitly recognized by the formal reward system" (1988: 4).

Recent studies have revealed that OCB's research in managementrelated fields such as strategic management and leadership is increasing dramatically (OCB research shows that miniaturization and rights respond to economic pressures and for human resource management, etc. (May-Chiun Lo et al., 2009). Literature reveals that OCB has contributed positively to Organizational outcomes such as service quality (Bhal, 2006; Lo, Ramayah \& Jerome, 2006) ,(Bettencourt \& Brown, 1997; Bell \& Mengue, 2002), Organization Commitment (Podsakoff, Mckenzie \& Bommer, 1996), Labor Involvement (Dimitriades, 2007), leader-member exchange (Bhal, 2006; Lo, Ramayah \& Jerome, 2006). Organ (1988) stated that the act of job performance beyond the stated job requirement views by the OCB as the extra-role behavior. A change in the definition of OCB means that it is difficult to describe the dimension or to specify its cause. Many different functions result from the OCB driver and predictor. This research has been categorized into two main themes that help analyze and promote citizenship action (Somech and Drach-Zahavy, 2004).

The OCB consist of different types of behavior. understanding the types of behavior (and premises) is a convenient way for employees to identify and encourage them. In the literature review, Podaskoff et al. stated the dimensions of OCB, "sportsmanship, organizational royalty, organizational compliance, individual initiative, civic virtue, and self-development". There are individuals (OCBI) that will benefit the whole organization and OCB that will benefit OCB (OCBO). McNeely and Meglino (1994) discovered that OCBI is related to individual treatment, such as empathy, whereas OCBO is related to organizational context. Thus, administrators who wish to enable actions that would benefit the organization need to consider what structures make them easier, and contract procedures take into account the functions associated with individual OCBs You can put it.

Many studies still use the five dimensions of OCB components "(altruism, courtesy, sportsmanship, civic ethics and responsibility)" 
Mackenzie et al. (1993), and these dimensions are used to measure the behavior of organizational citizenship because they were in previous research,(Bell \& Menguc, 2002) and (Yoon \& Suh, 2003) argue that altruism is a free act that can help others to respect to Organization related tasks or problems (for example, volunteering to help new employees with fewer skills and helping overworked or absent colleagues); the responsibility is a discretionary behavior that exceeds the minimum requirements work, do things that are not belong to responsibility, maintain organizational rules and not waste work time.; sportsmanship includes behaviors that employees should avoid, complain, make a small dissatisfaction, attack real or imagined trivia, and make federal cases with small potatoes; courtesy includes behaviors that help prevent problems related to working with others, or "touching the ground" with those whose work is influenced by someone's decision or commitment; Civic ethics reflects the responsible participation of employees Behavior, which demonstrates the initiative of organizations and employees by recommending how organizations can improve their operations. However, according to (Yoon and Suh, 2003), courtesy is not easy to distinguish from altruism; When a person is different from helping someone who already has problems and preventing problems, they can distinguish between the two behaviors.

The psychological characteristics of employees are directly or indirectly influenced by organizational culture which may be include OCB in recent years (Stamper and Van Dyne 2001). The attention in management literature and psychology has increased. The agency treats organizational behavior as arbitrary individual behavior and cannot be directly and explicitly declared through a formal organizational certification system, which generally increases the efficiency of the organization. Arbitrary means that behavior is not a labor responsibility or role, and it is not a commitment to recruit an employee, but an elective, and if it is not implemented, it will not be punished (Podsakoff et al., 2000). These actions lead to beneficial and beneficial behaviors to the organization by maintaining emotional and societal support, and are not yet completed at the time of application" (taxation in 2004). OCBs "behaviors are practical behavior, useful behavior and social behaviors (Alotaibi 2001). Graham (1991) suggest an OCB model and recognized three elements, "organizational obedience, organizational loyalty; and organizational association".

The compliance of the organization to the behavior described in this term determines the convenience of accepted structures and reasonable disciplines. Corporate compliance metrics are behaviors such as respecting presentation rules, completing tasks and responsibilities with respect to the resources of the organization. Organizational loyalty is the same to oneself loyalty to other individuals and organizational units, and indicates that 
employees are faithful to caring and defending the expression of organizational values. The term organizational partnership is attended by the contribution of employees in corporate governance, to share ideas and understand current problems we should participate in any meeting (Bienstock et al., 2003).

\section{Organizational Commitment:}

Because the commitment in the management literature is important, the fundamental values on which the organization is based, and employees evaluate carried according to its criteria (Cohen, 1993). Organizational commitment is a factors in the certified behavior of the staff, emotions (Bienstock et al., 2003), and is an attitude and emotional state that displays the trend growth rate and necessity, and maintains the duty of work in the organization. Organizational commitments are defined as an attitude or alignment to the organization of the identity of the person showing the organization (Gottham et al., 2004) and the feelings going to the organization (Markwitz et al., 2008) and the trend of persons to invest energy and loyalty. (Kim and leong 2005) on the basis of the social system (Meyer et al., 2002) found its identity in the organization. Organizational commitment can be defined as a state of mind that characterizes the relationship between an employee and an organization and reduces the likelihood that he or she will leave (Allen and Meyer, 2000). In addition, Allen and Meyer (2000) pointed out that organizational psychologists have studied several variables of work attitude, and in these studies only.

In the management literature commitment is an important issue. This hint considered to be is one of the essential values on which the organization is based, and employees evaluate it according to the commitment factors (Cohen, 1993). the employees' professional behavior and emotions affect Organizational commitment (Bienstock et al., 2003), which is an attitude and emotional state that shows the need for trends, growth rate and responsibility for keeping work in the organization. Attitudes or directions to organizational identity are defend by OC (Gottham et al., 2004) and organizational perceptions (Markwitz et al., 2008) and trends in people's energy and loyalty. (Kim and leong 2005) found their identity in the organization based on the social system (Meyer et al., 2002). A state of mind that characterizes by OC clarified as the relationship between employees and organizations and reduces the likelihood that they will leave (Allen and Meyer, 2000). In addition, Allen and Meyer (2000) pointed out that organizational psychologists have studied several variables of work attitude, and only in these studies

When job attitude variables include job satisfaction this considered to be more than organizational commitment. To maintain organizational loyalty referred to organization Organizational commitment the employee's should 
belief in the organization's goals and values (Mowday et al. 1983; Hackett et al., 2001). In addition, close relationship between people's identity and their participation in the organization served by organizational commitment (Mowday et al., 1979). Meyer and Allen (1990) Stated the organizational commitment model consist of three dimensions, "(emotional commitment, commitment continuity; and normative commitment)". The employee's emotional attachment to an organization's identity and commitment to organizational activities are included in Emotional Commitment. the inclination to stay in the organization due to the organization's rotation costs or the rewards left in the organization were included in Commitment to continuity. the personal feeling that people stay in the organization was included in regulatory commitments.

\section{Organizational citizenship behavior and organizational commitment;}

The background and reviewed the work of other researchers in the field by a number of researchers. A three-component model that included emotional commitment, continuing commitment, and normative commitment were developed by Meyer and Allen (1990) clarify that a commitment founded on one's values is emotional commitment, a commitment founded on obligations is continuous commitment, and commitment founded on calculations of costs and benefits is normative commitment. Gautam and others conduct a study in Nepal. (2005) effect of OCB and organizational commitment, on five organization total employees is 450 . The results showed that there is an effect of OCB on organizational commitment (Gautam et al., 2005). Haigh and Pfau (2006) the results showed in their study entitled "Strengthening of organizational identity, commitment and citizenship through the vaccination process" that organizational identity, organizational commitment and certain CBOs can be supported through internal communication (Haigh and Pfau) 2006). Lavelle et al. (2009), the results showed in their study entitled "Commitment, procedural justice and organizational citizenship: multiplefocus analysis", concluded that: (1) the positive relation between commitment and $\mathrm{OCB}$, and mediation

A positive relationship between procedural justice and OCB is found in the layoff survivors (Study 1) and the student project, and this relationship may mainly occur in the similarity effects of these goals. on. Team (Study 2) When the structure involves the same goal, the commitment was positive (Lavelle et al., 2009). The results of $\mathrm{Ng}$ and Feldman (2011) show that their study is entitled "Organizational Emotional Commitment and Citizenship: The Impact of Linear and Nonlinear Regulation of Organizational Terminology", which is moderately mitigated by organizational tenure. In the first ten years of the term, the strong relationship increases of the commitment-OCB 
increases the organization's tenure, after which the strength of the commitment-OCB relationship decreases as the organization's tenure increases. In summary, the adjustment effect of the term follows the curve model (Ng and Feldman 2011).

Morin et al. (2011) concludes in a study entitled "Emotional Commitment and Citizenship Behavior through Multiple Approaches" that contacts with colleagues, clients, and supervisors have a positive relationship with community organizations that focus on parallel approaches. In addition, the commitment to global organizations mediates and negatively mediates the relationship between contacts with colleagues and customers and the parallel dimensions of OCB. The results also reveal cross-reference relationships between local commitments and community organizations. Finally, there is no commitment target that is significantly associated with organizational management $\mathrm{OCB}$, but the latter is positively correlated with local OCB (Morin et al., 2011). Mirabizadeh and Gheitasi (2012) conducted a study in Iran entitled "Organizational Research on Organizational Commitment: A Case Study at Elan University": educational opportunities, work life policies , rights activities, organizational commitment and organizational commitment affected OCB (Mirabizadeh and Gheitasi 2012). Chen and Kao (2012) in a study entitled "Working Values and Service-Oriented Organizational Citizenship: Mediation of Psychological Contracts"

Professional Commitment: The Student Case of the Taiwan Police School "considered that psychological contracts and professional commitments have a positive impact on service-oriented OCBs. In addition, through the mediation of psychological contracts and professional commitments, the value of work is found for service-oriented Positive impact OCB (Chen and Kao) 2012. Previous studies have shown that commitment is a predictor of OCB because it has a significant impact on OCB (Liu 2009; Islam et al.al 2012).

\section{Theoretical Framework:}

The research consists of variables as shown in Fiq1:

Dependent variable: Organizational Citizenship Behavior (altruism, courtesy, Conscientiousness, sportsmanship, and civic virtue).

Independent variables: Organizational Commitment (Affective Commitment, Continuous Commitment \&Normative Commitment) 


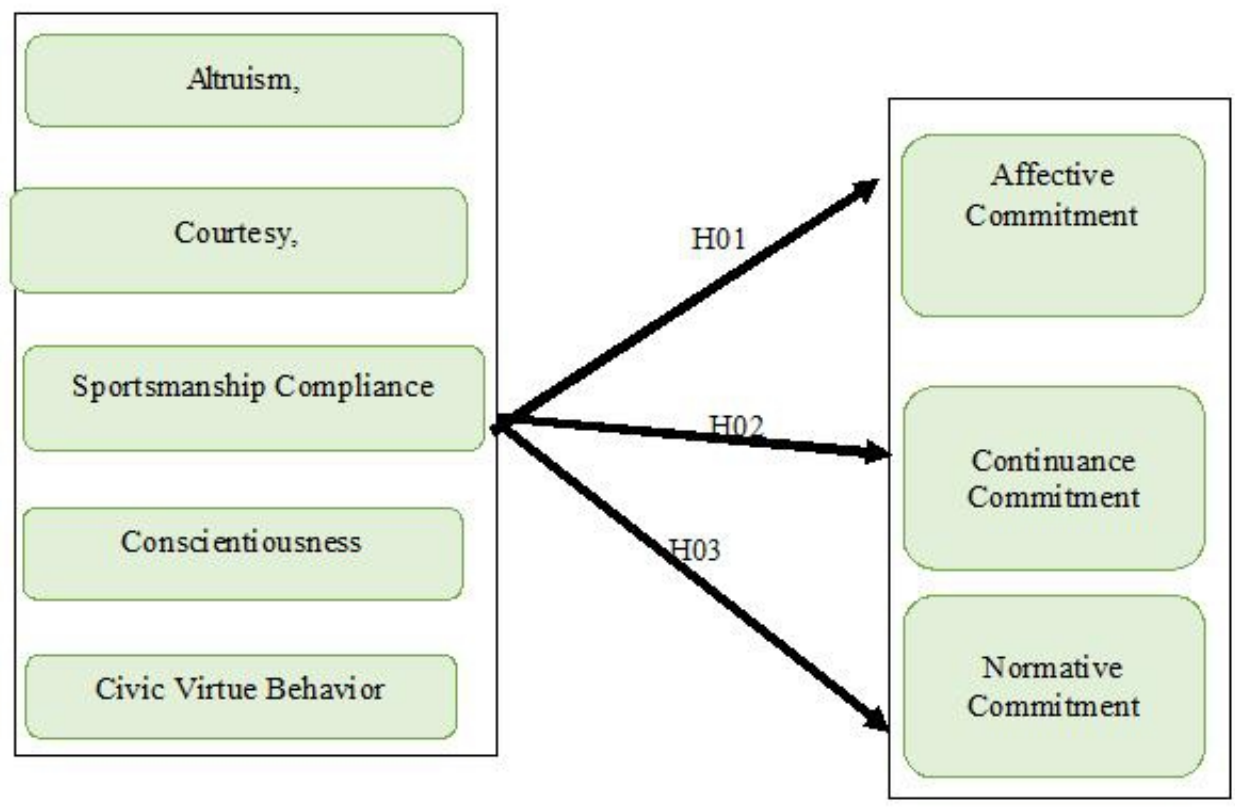

Figure (1) clarifies the study model.

\section{Statement of Problem}

This study investigates the impact of organizational citizenship behavior on organizational commitment, many similar studies have focused on the operations of businesses in developed countries, Similarly, rare researchers have been studied impact of organizational citizenship behavior on organizational, in addition to that, it is felt that there is need to study such important subjects in the Arab countries. This study conducted in Arabic bank frontline empowered employees in Amman capital, beside that the researchers identified the problem through literature, researches and studies, which recommended further study on this subject Hassan, et, al ,2013; Gautam, et, al 2004\& 92005; Ng and Feldman (2011).

Therefore, the purpose of the study is to measure the impact of impact of organizational citizenship behavior (altruism, courtesy, Conscientiousness, sportsmanship, and civic virtue) on organizational commitment (Affective Commitment, Continuous Commitment \&Normative Commitment). on Jordanian frontline employees of Arabic Bank. 


\section{Hypotheses:}

The following hypotheses are stated and will be tested with the purpose of achieving the aim of the study:

\section{Main Hypothesis:}

H0: There is no statistically significant impact at the level of significance $(0.05=\alpha)$ of organizational citizenship behavior (altruism, courtesy, Conscientiousness, sportsmanship, and civic virtue) on organizational commitment (Affective Commitment, Continuous Commitment \&Normative Commitment) on employees of Arabic Bank.

\section{Sub-hypothesis:}

H01: There is no statistically significant impact at the level of significance $(0.05=\alpha)$ of organizational citizenship behavior (altruism, courtesy, Conscientiousness, sportsmanship, and civic virtue) on Emotional Commitment on employees of Arabic Bank.

H02: There is no statistically significant impact at the level of significance $(0.05=\alpha)$ of organizational citizenship (altruism, courtesy, Conscientiousness, sportsmanship, and civic virtue) on Continuous Commitment on employees of Arabic Bank.

H03: There is no statistically significant impact at the level of significance $(0.05=\alpha)$ of organizational citizenship behavior (altruism, courtesy, Conscientiousness, sportsmanship, and civic virtue) on Normative Commitment on employees of Arabic Bank.

\section{Study Methodology:}

The research uses the descriptive-analytical approach to study its problem and test its hypotheses to achieve its objectives and importance. It provides information on the reality of the variables and the relationship between two variables, which helps to know the relationship between cause and effect and benefit from it. As well as, this study empirically investigates the impact of organizational citizenship on organizational commitment of Jordanian frontline employees of Arabic Bank.

\section{Study population and sampling unit:}

The study population consists of the mangers, Assistant mangers and heads of departments in the 52 branches of the Arab Bank in the capital Amman. The sample of the study was taken in a comprehensive survey of all the managers, assistant of managers and heads of the sections operating in these branches which are 128 individuals, 128 questionnaires were distributed to the members of the sampling unit, and retrieved 126 questionnaires. 


\section{Sources of data collection and information}

The current study is based on two sources:

1. Secondary sources: The researcher sought in this aspect to analyze the content through the analysis of the opinions of the researchers who wrote in the field of study variables. The researcher in this side used books, journals, theses.

2. Primary source: In this aspect, the researcher resorted to the questionnaire as the main tool for the study, as it is the main technique in collecting the data for the phenomenon to be subjected to classification, treatment, testing, analysis and presentation.

The researcher used questionnaires to cover the dimensions of the study and its variables, which will be distributed to the selected sample members and collected after being filled by the respondents as follow:

Section One: Personal Demographic Characteristics. Were collected with closed-ended questions, through (5) Characteristics (Age; Gender; Years of Experience, Qualification and Job Title).

Section Two: Organizational Citizenship. This section was measured behavior (altruism, courtesy, Conscientiousness, sportsmanship, and civic virtue) The altruism, consists of (6) paragraphs; The courtesy consists of (6) paragraphs. The sportsmanship, consists of (6) paragraphs, the consciousness, consists of (6) paragraphs; and the civic virtue behavior, consists of (8) paragraphs

Section Three: Organizational commitment. This section was measured through (3) dimensions The emotional commitment, consists of (6) paragraphs; continuous commitment, consists of (5) paragraphs \& moral obligation, consists of (6) paragraphs

Table (1) The extent of the response in the questionnaire according to the five Likert scale

\begin{tabular}{|c|c|c|c|c|}
\hline Strongly Agree & Agree & Neutral & Disagree & $\begin{array}{c}\text { Strongly } \\
\text { Disagree }\end{array}$ \\
\hline 5 & 4 & 3 & 2 & 1 \\
\hline
\end{tabular}

Personal and Occupational Characteristics of the sampling unit

Table ( 2 ) ) Personal and Occupational Characteristics of the sampling unit

\begin{tabular}{|c|c|c|c|}
\hline Variable & Categories & Frequency & Percentage \\
\hline \multirow{3}{*}{ Gender } & Male & 83 & 65.9 \\
\cline { 2 - 4 } & Female & 43 & 34.1 \\
\cline { 2 - 4 } Age & & $\mathbf{1 2 6}$ & $\mathbf{1 0 0 . 0}$ \\
\cline { 2 - 4 } & $24-29$ & 20 & 15.9 \\
\cline { 2 - 4 } & $30-35$ & 42 & 33.3 \\
\cline { 2 - 4 } & $36-41$ & 28 & 22.2 \\
\cline { 2 - 4 } & $42 \&$ More & 36 & 28.6 \\
\hline
\end{tabular}




\begin{tabular}{|c|c|c|c|}
\hline \multirow{3}{*}{ Job Title } & Total & $\mathbf{1 2 6}$ & $\mathbf{1 0 0 . 0}$ \\
\cline { 2 - 4 } & Manger & 50 & 39.7 \\
\cline { 2 - 4 } & Manger Assistant & 17 & 13.5 \\
\cline { 2 - 4 } & Head of Section & 59 & 46.8 \\
\hline Qualification & Total & $\mathbf{1 2 6}$ & $\mathbf{1 0 0 . 0}$ \\
\cline { 2 - 4 } & Secondary & 0 & 0 \\
\cline { 2 - 4 } & Diploma & 5 & 4 \\
\cline { 2 - 4 } & Bachelor & 108 & 85.7 \\
\cline { 2 - 4 } & Master & 13 & 10.3 \\
\cline { 2 - 4 } & Ph.D. & 0 & 0 \\
\hline Experience & Total & 126 & $\mathbf{1 0 0 . 0}$ \\
\cline { 2 - 4 } & $1-5$ & 43 & 34.9 \\
\cline { 2 - 4 } & $6-10$ & 24 & 19 \\
\cline { 2 - 4 } & $11-15$ & 49 & 38.9 \\
\cline { 2 - 4 } & $16 \&$ More & $\mathbf{1 2 6}$ & $\mathbf{1 0 0 . 0}$ \\
\cline { 2 - 4 } & Total & & 34.1 \\
\hline
\end{tabular}

Tables (2) show the Personal and Demographic Characteristics of the sampling unit (Age; Gender; Qualification; Years of Experience and Job Title). 1. Age: It was found that (33.3) from the study sampling unit than 30-35 years and the lowest is (15.9) from the study sampling unit were aged from 2429 years.

These indicates the high concentration in employees of Arabic Bank were the human youth

2. Gender: It was found that (65.9\%) were male, while (34.1) of the respondents were females.

These indicates the high concentration in employees of Arabic Bank were males.

3. Qualification: It was found that (4\%) of respondents had College Diploma, while (85.7) of respondents had bachelor's degrees, (10.3\%) of respondents had a master's degree. This evidence of the high Qualification levels in employees of Arabic Bank.

4. Years of Experience: The previous table showed that (7.9\%) of respondents had experience less than 5 years, $(34.1 \%)$ of respondents had experience 5 to less than 10 years, (19\%) of respondents had experience 10 to less than 15 years. Finally, (38.9\%) of respondents had experience 15 years or more.

This reflects the precise nature of the work in Arabic Bank, requires high levels of expertise,

5. Job Title: Descriptive analysis of the Job Title in the table (4-1) shows that the $(39.7 \%)$ from the study sampling unit were manager, (13.5\%) from the 
study sampling unit were manager assistant, (46.8\%) from the study sampling unit were Head of Department.

\section{Statistical Treatment}

Statistical Package for Social Sciences "SPSS Ver.22" were used for analyzing through:

Percentage and Frequency, Means and Standard Deviation.Cronbach Alpha to test reliability. And Multiple Regression analysis to test the impact of organizational Citizenship on Organizational Commitment

\section{Validity}

The survey was pre-tested by (10) instructors PhD qualifications, from Amman Arab University and other universities, practitioners and their major is Business Administration to ensure that the survey constructed probably. A few comments added about the survey. The comments have been taken into consideration. the overall percentage of respond is $(100 \%)$.

\section{Reliability}

The reliability was assessed through Cronbach's alpha test, according to the scale of Sakran\& Bouge)(2013) stated that the results should be (0.60) or higher to indicate internal consistency. The results shown in Table (3-1) are acceptable since it does not exceed (.060)

Table (3) the coefficient of consistency of the internal dimensions of the resolution

\begin{tabular}{|c|c|}
\hline Dimensions & Cronbach Alpha \\
\hline Independent Dimensions \\
\hline altruism & 0.918 \\
\hline courtesy & 0.925 \\
\hline Conscientiousness & 0.930 \\
\hline sportsmanship & 0.925 \\
\hline civic virtue behavior & 0.923 \\
\hline Average & 0.917 \\
\hline \multicolumn{2}{|c|}{ Dependent Dimensions } \\
\hline Affective Commitment & 0.909 \\
\hline Continuous Commitment & 0.604 \\
\hline Normative Commitment & 0.744 \\
\hline Average & 0.861 \\
\hline
\end{tabular}

Table (3) shows that the highest stability factor for the dimensions of the questionnaire was (0.930) for the dimension of the sportsmanship while the lowest value of the stability was $(0.744)$ for the dimension of the moral obligation, while the scale as a whole for the dimensions of the independent variable $(0.917)$ With the accepted proportion of research and studies that rely 
on the opinion of the human element. The scale as a whole measures the dimensions of the dependent variable $(0.861)$, which is high compared with the accepted percentage in human-centered research and studies, indicating that the tool has a high stability coefficient and the ability of the tool in general to achieve the objectives of the study (George andMalleny,2003).

Descriptive Statistics: The Mean and standard deviations of all areas of the study instrument were extracted.

Table (3) The statistical averages and standard deviations of the fields of organizational citizenship behavior.

\begin{tabular}{|c|c|c|c|}
\hline No & Dimensions & Means & St Deviation \\
\hline 1 & altruism & 4.02 & 0.65 \\
\hline 2 & courtesy & 4.26 & 0.64 \\
\hline 3 & Conscientiousness & 3.78 & 0.76 \\
\hline 4 & sportsmanship & 4.31 & 0.52 \\
\hline 5 & civic virtue behavior & 4.43 & 0.46 \\
\hline & Average & $\mathbf{4 . 1 6}$ & \\
\hline
\end{tabular}

Table 3 shows that all dimensions of citizenship behaviors were high, ranging from 4.02 to 4.43 , and the general mean was 4.21 , which is high and indicates a high degree of behavior.

Table (4) arithmetical averages and standard deviations of the areas of organizational commitment.

\begin{tabular}{|c|c|c|c|}
\hline No & Dimensions & Means & St Deviation \\
\hline 1 & Affective Commitment & 3.71 & 0.780 \\
\hline 2 & Continuous Commitment & 3.53 & 0.810 \\
\hline 3 & Normative Commitment & 3.33 & 0.587 \\
\hline & Average & 3.52 & 0.725 \\
\hline
\end{tabular}

Table 4 shows that the trends of the sample of the study are positive towards all the variables of the organizational commitment. This indicates that there is an organizational commitment at the branches of the Bank, and that the degree of availability is high. It also shows that the types of organizational commitment used in this research are all present. The highest level of organizational commitment is that the organizational commitment of the bank is emotional commitment, and this is explained by the friendly relations existing between the employees followed by the continuous commitment and then the moral obligation is available to a medium degree.

\section{Hypothesis Test:}

Main Hypothesis:

H0: There is no statistically significant impact at the level of significance $(0.05=\alpha)$ of organizational citizenship behavior (altruism, courtesy, Conscientiousness, sportsmanship, and civic virtue) on organizational 
commitment (Affective Commitment, Continuous Commitment \&Normative Commitment) on Jordanian frontline employees of Arabic Bank.

Simple Linear Regression was applied to detect the impact of organizational citizenship behavior (altruism, courtesy, Conscientiousness, sportsmanship, and civic virtue) on organizational commitment (Affective Commitment, Continuous Commitment \&Normative Commitment) on Jordanian frontline employees of Arabic Bank.

Table (5): Simple Linear Regression analysis to detect the effect of the relationship between independent and sequential change

\begin{tabular}{|c|c|c|c|c|c|c|}
\hline Variables & $\mathbf{R}$ & (R2) & $(\beta)$ & (F) & Sig & Result \\
\hline Organizational Citizenship & \multirow{2}{*}{$0.768^{a}$} & \multirow[t]{2}{*}{.5900} & \multirow[t]{2}{*}{.7680} & \multirow[t]{2}{*}{265.838} & \multirow{2}{*}{$0.000^{\mathrm{a}}$} & \multirow{2}{*}{ رفض } \\
\hline Organizational Commitment & & & & & & \\
\hline
\end{tabular}

The results show that the value of $(\mathrm{R})$ was $(0.768)$ and the value is the strength of the relation between the behavior of organizational citizenship and organizational commitment, $\left(\mathrm{R}^{2}\right.$ ") value $(0.590)$ which asserted that $(0.590)$ of the explained variation in organizational Commitment in employees of Arabic Bank can be accounted for OCB.

The independent variable impact on the dependent variable, the value of $\mathrm{F}$ (265.838) was statistically significant (0.00). which is more than tabulated value (2.50) therefore the null hypothesis will be rejected and the alternative one accepted, this indicates a statistically significant impact of the organizational citizenship behavior on organizational commitment at the level of significance (0.05).

\section{Sub-hypothesis one:}

H01: There is no statistically significant impact at the level of significance $(0.05=\alpha)$ of organizational citizenship behavior (altruism, courtesy, Conscientiousness, sportsmanship, and civic virtue) on Affective Commitment of employees of Arabic Bank

Table (6) Multiple Regression analysis to detect the impact of organizational citizenship behavior on its emotional commitment

\begin{tabular}{|c|c|c|c|c|c|c|c|}
\hline \multirow{2}{*}{$\begin{array}{c}\text { Organizational } \\
\text { Citizenship }\end{array}$} & \multicolumn{7}{|c|}{ Organizational Commitment } \\
\hline & (f) & Sig & $\mathbf{R}$ & $\mathbf{R}^{2}$ & (B) & (t) & Sig \\
\hline altruism & \multirow{5}{*}{$\begin{array}{c}44.9 \\
79\end{array}$} & \multirow{5}{*}{$\underset{\mathrm{a}}{0.000}$} & \multirow{5}{*}{$\underset{\mathrm{a}}{0.651}$} & \multirow{5}{*}{0424} & 0.045 & 0.606 & 0.545 \\
\hline courtesy & & & & & 0.464 & 5.791 & 0.000 \\
\hline Conscientiousness & & & & & 0.217 & 2.970 & 0.003 \\
\hline sportsmanship & & & & & 0.215 & 1.955 & 0.456 \\
\hline civic virtue behavior & & & & & 0.1 .95 & 2.123 & 0.325 \\
\hline
\end{tabular}

Table (6) shows that the value of (R) was 0.651 is the strength of the relation between the behavior of organizational citizenship with its dimensions and Affective commitment (" $\mathrm{R}^{2 "}$ ) value (0.424), which asserted that $(0.424)$ 
of the explained variation in Affective Commitment in employees of Arabic Bank can be accounted for OCB.

There is a statistically significant effect of the independent variable on the dependent variable, (f) calculated (44.979) in statistical terms (0.00). which is more than tabulated (2.5) therefore the null hypothesis will be rejected and the alternative accepted This indicates that there is an impact of the behavior of organizational citizenship by its exclusion on Affective commitment.

The results also indicate that (courtesy, Conscientiousness) has an impact on Affective commitment on employees of Arabic Bank with a coefficient of (0.464); (0.217). As well as, the results show the altruism (0.045), sportsmanship (0.215) and civic virtue behavior (0.1951) was not significant impact on Affective commitment of employees of Arabic Bank

\section{Sub-hypothesis two:}

H02: There is no statistically significant impact at the level of significance $(0.05=\alpha)$ of organizational citizenship (altruism, courtesy, Conscientiousness, sportsmanship, and civic virtue) on Continuous Commitment of employees of Arabic Bank.

Table (7) Multiple Regression analysis to detect the behavior of organizational citizenship in its dimensions on continuous commitment

\begin{tabular}{|c|c|c|c|c|c|c|c|}
\hline Organizational & \multicolumn{7}{|c|}{ Organizational Commitment } \\
\hline & (f) & Sig & $\mathbf{R}$ & $\mathbf{R}^{2}$ & ( $\beta)$ & $(t)$ & Sig \\
\hline altruism & \multirow{5}{*}{44.741} & \multirow{5}{*}{0.000} & \multirow{5}{*}{$\begin{array}{c}0.65 \\
1^{\mathrm{a}}\end{array}$} & \multirow{5}{*}{0423} & .2090 & 2.793 & $\begin{array}{c}.006 \\
0\end{array}$ \\
\hline courtesy & & & & & .3320 & 4.140 & $\begin{array}{c}.000 \\
0\end{array}$ \\
\hline Conscientiousness & & & & & .215 & 2.942 & $\begin{array}{c}.004 \\
0\end{array}$ \\
\hline sportsmanship & & & & & 0.133 & 1.951 & $\begin{array}{c}0.00 \\
3\end{array}$ \\
\hline civic virtue behavior & & & & & 0.123 & 1.991 & $\begin{array}{c}0.00 \\
2\end{array}$ \\
\hline
\end{tabular}

Table (7) shows that the value of (R) was 0.651 and the value of is the strength of the relation between the behavior of organizational citizenship with

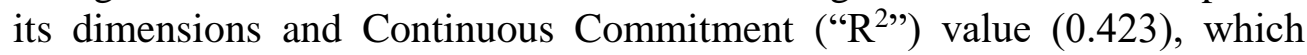
asserted that (0.423) of the explained variation in Continuous Commitment in employees of Arabic Bank can be accounted for OCB

There is a statistically significant impact of the independent variable on the dependent variable, (f) calculated (44. 741) in statistical terms (0.000). which is more than tabulated (2.5) therefore the null hypothesis will be rejected and the alternative accepted This indicates that there is an impact of the organizational citizenship behavior on Continuous commitment. 
The results also indicate that (altruism, courtesy, Conscientiousness, sportsmanship, and civic virtue) has significant impact on emotional commitment of Jordanian frontline employees of Arabic Bank with a coefficient of (.2090), (.3320); (.215), (0.133) and (0.123).

\section{Sub-hypothesis three:}

H03: There is no statistically significant impact at the level of significance $(0.05=\alpha)$ of organizational citizenship behavior (altruism, courtesy, Conscientiousness, sportsmanship, and civic virtue) on Normative Commitment of employees of Arabic Bank.

Table (8) Multiple regression analysis to detect the impact of organizational citizenship behavior in its dimensions on the normative commitment

\begin{tabular}{|c|c|c|c|c|c|c|c|}
\hline Organizational & \multicolumn{7}{|c|}{ Organizational Commitment } \\
\hline & (f) & Sig & $\mathbf{R}$ & $\mathbf{R}^{2}$ & $(\beta)$ & (t) & Sig \\
\hline altruism & \multirow{5}{*}{$\begin{array}{c}61.27 \\
2\end{array}$} & \multirow{5}{*}{$\begin{array}{c}0.00 \\
0^{\mathrm{a}}\end{array}$} & \multirow{5}{*}{$\begin{array}{c}.708 \\
0^{\mathrm{a}}\end{array}$} & \multirow{5}{*}{$\begin{array}{c}.501 \\
0\end{array}$} & $\begin{array}{c}.291 \\
0 \\
\end{array}$ & $\begin{array}{c}4.18 \\
4\end{array}$ & $\begin{array}{l}.00 \\
00 \\
\end{array}$ \\
\hline courtesy & & & & & $\begin{array}{c}.370 \\
0\end{array}$ & $\begin{array}{c}4.95 \\
8\end{array}$ & $\begin{array}{l}.00 \\
00\end{array}$ \\
\hline Conscientiousness & & & & & $\begin{array}{c}.156 \\
0 \\
\end{array}$ & $\begin{array}{c}2.29 \\
9 \\
\end{array}$ & $\begin{array}{l}.02 \\
30 \\
\end{array}$ \\
\hline sportsmanship & & & & & $\begin{array}{c}0.11 \\
6 \\
\end{array}$ & $\begin{array}{c}2.14 \\
7 \\
\end{array}$ & $\begin{array}{l}0.0 \\
03 \\
\end{array}$ \\
\hline civic virtue behavior & & & & & $\begin{array}{c}0.14 \\
4\end{array}$ & $\begin{array}{c}2.18 \\
5\end{array}$ & $\begin{array}{l}0.0 \\
02 \\
\end{array}$ \\
\hline
\end{tabular}

Table (8) shows that the value of (R) was 0.708 and the value of is the strength of the relation between the behavior of organizational citizenship and Normative Commitment (" $\mathrm{R}$ ") value $(0.708)$ which asserted that $(0.708)$ of the explained variation in Normative Commitment in employees of Arabic Bank can be accounted for OCB

There is a statistically significant effect of the independent variable on the dependent variable, (f) calculated (61.272) in statistical terms (0.000). which is more than tabulated (2.5) therefore the null hypothesis will be rejected and the alternative accepted This indicates that there is an impact of the organizational citizenship behavior on normative commitment.

The results also indicate that (altruism, courtesy, Conscientiousness, sportsmanship, and civic virtue) has significant impact on emotional commitment of Jordanian frontline employees of Arabic Bank with a coefficient of $(0.2910) ; 0.3700) ;(0.1560),(0.144)$ and $(0.123)$.

\section{Conclusions:}

There is statistically significant impact at the level of significance $(0.05$ $=\alpha$ ) of organizational citizenship behavior (altruism, courtesy, Conscientiousness, sportsmanship, and civic virtue) on organizational commitment (Affective Commitment, Continuous Commitment \&Normative 
Commitment) on employees of Arabic Bank. These results agree with Nepal. (2005) study results. There is statistically significant impact at the level of significance $(0.05=\alpha)$ of organizational citizenship behavior (courtesy, Conscientiousness on Emotional Commitment of Jordanian frontline employees of Arabic Bank The degree of behavior of organizational citizenship in its dimensions in the bank was high. As well as, the results show the altruism sportsmanship and civic virtue behavior were insignificant impact on emotional commitment of employees of Arabic Bank, these results differ with Morin et al. (2011) study results that revealed positive relationship with CBOs and there is statistically significant impact at the level of significance $(0.05=\alpha)$ of organizational citizenship behavior) (altruism, courtesy, Conscientiousness, sportsmanship, and civic virtue) on Continuous Commitment on employees of Arabic Bank.

\section{Recommendations:}

The management of Arabic bank could attempt to improve the efficiency not concentrate only on improving say infrastructure, rewards, improving technologies and their likes only, rather management, aside considering these factors should also have a critical look at the factors that influences citizenship behavior and employee commitment. The management of Arabic bank can improve their staff citizenship behavior by working on proving the commitment of the employees and the management of Arabic bank could attempt to improve the efficiency of the organization, not concentrating only on improving say infrastructure, rewards, improving technologies and their likes only, but should considering to critical factors that influences citizenship behavior and employee commitment Further researches could measure effect of leadership style, organizational commitment, and OCB simultaneously beside measuring the employees' perceptions to enhance positive organizational commitment.

\section{References:}

1. Allen, N. J., \& Meyer, J. P. (2000). Construct validation in organizational behavior research: The case of organizational commitment. Problems and Solutions in Human Assessment (pp. 285314). New York: Springer.

2. ALotaibi, A. G. (2001). Antecedents of organizational citizenship behavior a study of public personnel in Kuwait. Public Personnel Management, 30(3), 350-363.

3. arkovits, Y., Ullrich, J., van Dick, R., \& Davis, A. J. (2008). Regulatory foci and organizational commitment. Journal of Vocational Behavior, 73(3), 485-489. 
4. autam, T., Van Dick, R., Wagner, U., Upadhyay, N., \& Davis, A. J. (2005). Organizational citizenship behavior and organizational commitment in Nepal. Asian Journal of Social Psychology, 8(3), 305314.

5. Bell, S. \& Menguc, B. (2002). The employee-organization relationship, organizational citizenship behaviors, and superior service quality. Journal of Retailing, 78, 2, 131-146.

6. Bettencourt, L. A. \& Brown, S. W. (1997). Contact employees: Relationship among workplace fairness, job satisfaction and prosocial behaviors. Journal of Retailing, 73, 39-61.

7. Bhal, K. T. (2006). LMX-citizenship behavior relationship: Justice as a mediator. Leadership \& Organization Development Journal, 27, 2, 106-117

8. Bienstock, C. C., DeMoranville, C. W., \& Smith, R. K. (2003). Organizational citizenship behavior and service quality. Journal of Services Marketing, 17(4), 357-378.

9. Chen, C. H. V., \& Kao, R. H. (2012). Work values and service-oriented organizational citizenship behaviors: The mediation of psychological contract and professional commitment: A Case of Students in Taiwan Police College. Social Indicators Research, 107(1), 149-169.

10. Cohen, A. (2006). The relationship between multiple commitment and organizational citizenship behavior is Arab and Jewish culture. Journal of Vocational Behavior, 69(1), 105-118.

11. Dickinson, L. (2009). An examination of the factors affecting organizational citizenship behavior. University of Tennessee, Knoxville, TN. p. 43.

12. Dimitriades, Z. S. (2007). The influence of service climate and job involvement on customer-oriented organizational citizenship behavior in Greek service organizations: A survey. Employee Relations, 29, 5 , 469-491.

13. Farhangi A, Fattahi M, Vasegh B, Nargesian A. (2009). Predictive intelligence, transformational leadership: Exploring the relationship between spiritual intelligence, emotional intelligence and transformational leadership. Journal of Iran Management Sciences, Year 4, No. 15, pp. 57-31.

14. Garg,P.,Rastigi,R. (2006). "Climate profile and OCBs of teachers in public and private schools of India". International Journal of Educational Management, 20 (7), 529-54.

15. Gautam, T., Van Dick, R., \& Wagner, U. (2001). Organizational commitment in Nepalese settings. Asian Journal of Social Psychology, 4, 239-248. 
16. Gautam, T., Van Dick, R., \& Wagner, U. (2004). Organizational identification and organizational commitment: Distinct aspects of two related concepts. Asian Journal of Social Psychology, 7(3), 301-315

17. George, D., \& Mallery, P. (2003). Using SPSS for Windows Step by Step A Simple Guide and Reference (4th ed.). London Pearson Education.

18. graham, J. W. (1991). An essay on organizational citizenship behavior. Employee Responsibilities and Rights Journal, 4(4), 249-270. doi: 10.1007/BF01385031.

19. Hackett, R. D., Lapierre, L. M., \& Hausdorf, P. A. (2001). Understanding the links between work commitments constructs. Journal of Vocational Behaviors, 58(3), 392-413.

20. Haigh, M. M., \& Pfau, M. (2006). Bolstering organizational identity, commitment, and citizenship behaviors through the process of inoculation. International Journal of Organizational Analysis, 14(4), 295-316.

21. Kim, W. G., Leong, J. K., \& Lee, Y-K. (2005). Effect of service orientation on job satisfaction, organizational commitment, and intention of leaving in a casual dining chain restaurant. Hospitality management, 24, 171-193. Available at

22. Lavelle, J. J., Brockner, J., Konovsky, M. A., Price, K. H., Henley, A. B., Taneja, A., et al. (2009). Commitment, procedural fairness, and organizational citizenship behavior: a multifocal analysis. Journal of Organizational Behavior, 30(3), 337-357

23. Liu, Y. (2009). Perceived organizational support and expatriate organizational citizenship behavior: The mediating role of affective commitment towards the parent company. Personnel Review, 38(3), 307-319.

24. Lo, M. C., Ramayah, T. \& Kueh, J. S. H. (2006). An Investigation of Leader Member Exchange Effects on Organizational Citizenship Behavior in Malaysia. Journal of Business and Management, 12, 1, 523.

25. MacKenzie, S. B., Podsakoff, P. M., \& Paine, J. E. 1998. Effects of organizational citizenship behaviors and productivity on evaluations of performance at different hierarchical levels in sales organizations. Journal of the Academy of Marketing Science, 27: 396-410.

26. Meyer, J. P., \& Allen, N. J. (1991). A three-component conceptualization of organizational commitment. Human Resources Management Review, 1(1), 61-89.

27. Mirabizadeh, M., \& Gheitasi, S. (2012). Examining the organizational citizenship behavior as the outcome of organizational commitment: 
Case study of universities in Ilam. Management Science Letters, 2(3), 951-960.

28. Morin, A. J. S., Vandenberghe, C., Boudrias, J. S., Madore, I., Morizot, J., \& Tremblay, M. (2011). Affective commitment and citizenship behaviors across multiple foci. Journal of Managerial Psychology, 26(8), 716-738.

29. Ng, T. W. H., \& Feldman, D. C. (2011). Affective organizational commitment and citizenship behavior: Linear and nonlinear moderating effects of organizational tenure. Journal of Vocational Behavior, 79(2), 528-537.

30. Organ, D. W. (1988). Organizational Citizenship Behavior - The Good Soldier Syndrome: (1st ed.). Lexington, Massachusetts/Toronto: D.C. Heath and Company

31. Podsakoff, P. M., Mackenzie, S. B., Paine, J. B., \& Bachrach, D. G. (2000). Organizational citizenship behaviors: A critical review of the theoretical and empirical literature and suggestions for future research. Journal of Management, 26(3), 513-563.

32. Rokninezhad, M. (2007). New theories and models of organizational commitment.

33. Somech, A., \& Drach-Zahavy, A. (2004). Exploring organizational citizenship behavior from an organizational perspective: The relationship between organizational learning and organizational citizenship behavior. Journal of Occupational and Organizational Psychology, 77, 281-298

34. Stamper, C.L. \& Van Dyne, L. (2003). Organizational citizenship: A comparison between part-time and full-time service employees. Cornell Hotel and Restaurant Administration Quarterly, 44(1), 33-43

35. Turnipseed, D.L., Rassuli, A., (2005). Performance perceptions of organizational citizenship behaviors at work: a bi-level study among managers and employees. British Journal of Management, 16, 231244.

36. Yoon, Mann. Hee, Suh, Jaebeom 2003 Organization Citizenship Behavior and Service Quality as External Effectiveness of Contact Employees, Journal of Business Research 56. Pp 597-611

37. Hasani, K, Boroujerdi, S \& Sheikhesmaeili, S; The effect of organizational citizenship behavior on organizational commitment Global Business Perspectives ;December 2013, Volum1, Issue 4, pp $452-470$

38. AL-Hussami, RN, A Study of Nurses' Job Satisfaction: The Relationship to Organizational Commitment, Perceived Organizational Support, Transactional Leadership, Transformational 
Leadership, and Level of Education; European Journal of Scientific Research ,ISSN 1450-216X Vol.22 No.2 (2008), pp.286-295

39. Mathauer I \& Imhoff I (2006). 'Health worker motivation in Africa: the role of nonfinancial incentives and human resource management tools', Human Resources for Health, vol. 4, article 24

40. Byars, L., \& Rue, L. (2008). Human Resource Management. Irwin: Mc Graw Hill.

41. Ramasodi, M.J. (2010). Factors influencing job satisfaction at South Rand Hospital. Available online at policyresearch.limpopo.gov.za/.../Factors\%20Influencing\%20 JO...

42. Parvin, Mosammod Mahamuda \& Kabir, M M Nurul, (2011) "Factors affecting employee job satisfaction of pharmaceutical sector", Australian Journal of Business and Management Research, Vol.1 No.9

43. Pouliakas, K., and Ioannis, T.,2010. "Differences in the Job Satisfaction of High-Paid and LowPaid Workers Across Europe." International Labour Review, 149(1): 1-29.

44. Clark, A, Nicolas Kristensen, and Niels Westergard-Nielsen., 2009. "Job Satisfaction and CoWorker Wages:Status or Signal?" Economic Journal 119: 430-47.

45. Skalli, A, Ioannis T., and Efi V., 2008. "Jobs as Lancaster Goods: Facets of Job Satisfaction and Overall Job Satisfaction." Journal of Socio-Economics, 37,1906-20.

46. Brown, Gordon D. A., Jonathan Gardner, Andrew Oswald, and Jing Qian., 2008. "Does Wage Rank AffectEmployees' Well-being?" Industrial Relations 47(3), 355-89.

47. Bygren, Magnus., 2004. "Pay Reference Standards and Pay Satisfaction: What Do Workers Evaluate TheirPay Against?". Social Science Research 33(2): 206-224. 